\begin{tabular}{|c|c|c|}
\hline $\begin{array}{l}\text { Editorial \& Publishing Offices : } \\
\text { Macmillan \& Co., LTD. } \\
\text { St. MaRTIN's StREET } \\
\text { LoNDON, W.C.2 }\end{array}$ & & $\begin{array}{l}\text { Telegraphic Address : } \\
\text { Phusis, Lmsquare, LoNDoN } \\
\text { Telephone Number: } \\
\text { WhItrhalL 883 }\end{array}$ \\
\hline Vol. I47 & SATURDAY, MARCH I, I94I & No. 3722 \\
\hline
\end{tabular}

\title{
A BASIS OF INTERNATIONAL CO-OPERATION
}

$\mathrm{I}^{\mathrm{s}}$ preparing for the new world order to be established after the War, we must clearly draw whatever conclusions we can from the experience of the last twenty years, seeking to embody the lessons we learnt in the constructive effort of framing a new peace settlement. The truth that nothing short of an economic revolution can give us security has been emphasized by many authorities of widely differing outlook, but the extent to which a foundation already exists for further constructive and creative effort is often overlooked. Notably is this true of the work of the International Labour Organization and of the non-political work of the League of Nations.

The last report of the director of the International Labour Office visualized the important contribution which the organization might make to human welfare even with the outbreak of war, and that forecast has in no way been invalidated with the removal of the Office to Montreal in view of the increasing difficulties of communication between Geneva and member States. From the quarters placed at its disposal by McGill University, as well as from the correspondence offices in London, Washington and Delhi, the organization is continuing its activities, albeit on a reduced scale, as well as assisting in surveying social and industrial changes brought about by the War. Not the least valuable of these activities are the admirable series of publications, including the International Labour Review, the Industrial Safety Survey, the "I.L.O. Yearbook", and "Yearbook of Labour Statistics", as well as further studies and reports, the issue of which is now to be resumed from the new home at Montreal.

The practical value of the work of the Inter- national Labour Organization in preparing peace, emphasized by the Secretary of Labour at Washington in November 1939, has indeed been accentuated as the struggle has intensified, and one country after another has been drawn into the War. The support afforded to the policy adopted by the governing body gives eloquent proof that the organization has an essential part to play at this critical juncture in the fortunes of civilization. That function is essentially a contribution to the preservation of the common heritage of civilization.

"The future of humanity depends upon the type of civilization which emerges from this war, the kind of world institutions which are constructed after it, and the intensity of the allegiance which they command, upon the common man, upon the nature of its impact upon political ideals and upon economic and social practice, upon the manner in which it affects the crisis in social evolution which dominates our time." Nothing which has occurred has invalidated this estimate by the Director of the Office in October 1939, and the existence of this agency for disinterested technical assistance, the concerting of practical measures to limit moral and national havoc within or without the war zone, and to maintain cooperation between Governments, employers and workers represents an immense advance on the forces available for reconstruction available in 1918.

If, indeed, the International Labour Organization represents in some measure that scientific detachment without which we may well be unable to achieve some of the essential reconstruction and rehabilitation, in the non-political achievements of the League of Nations itself there are equally 
sound reasons for hoping for an advance on the position of twenty-five years ago. To the value of these achievements an admirable article in the American quarterly Foreign Affairs by Mr. Arthur Sweetser, a director of the League secretariat, testifies. The League's own reverses, notably in the Disarmament and Economic Conferences and in the Manchurian and Ethiopian disputes, have distracted attention from its solid but less conspicuous successes. This distortion of our understanding of events since 1919 may conceal valuable clues as to the planning and rebuilding which lie ahead of us.

Mr. Sweetser rightly points out that any political institution is a reflection of the society from which it has sprung, and the League of Nations, in particular, has been a vivid expression of the period into which it was born. Its record is valuable both as an index of the stage which international life has at present attained, and as an augury of the course we may expect it to take in the future. The sharp interruption of the varied work of international co-operation carried out at Geneva for two decades, involving the cessation of conferences, drastic reduction of staff, and transfer of some of the technical services, commencing with the financial and economic, to the United States on the joint invitation of the three educational institutions at Princeton-the University, the Institute for Advanced Study, and the Rockefeller Institute for Medical Research-provides indeed a most appropriate opportunity for appraisal of these non-political achievements.

The value of such stocktaking is indisputable, for it is on the assets that remain that the new organization of international co-operation will be built. The need for such co-operation will tend to increase, not only because the ravages of war must be repaired, but also through the relentless advance of science, the continual widening search of industry for specialized materials and the growth of the world's population. Only international organization of the world's life can prevent another and even more calamitous disaster.

The impetus which the League has given to international co-operation is unmistakable. The provision by the League system of a permanent Civil Service supplied with funds and authority, and able to collect and preserve records and statistics, and to enlist and to use the services of experts from all countries, is one of the main reasons for the advances made in the last two decades in handling a wide range of technical questions, from financial and economic problems to the control of opium and other drugs and the consideration on an international scale of health, including nutrition.

Without going into the details of the League's remarkable achievements in these technical fields while international friction was reducing its effective political power to a mere shadow, they present several features which merit attention. A noteworthy part of the financial section and economic intelligence service is the provision of an admirable series of publications which give the world for the first time something of a detached scientific view of the problems covered by the section, in place of the partial or national point of view from which such matters have in general hitherto been approached. The development of this scientific approach and the introduction of something of the scientific spirit into the examination of all these technical matters well justifies General Smuts's observations in his Sidgwick Memorial Lecture. If this is indeed one reason for the success of the League in such technical fields, it may well hold a clue as to the correct approach in other fields also.

A second feature to which Mr. Sweetser directs attention is the unexpected quarters from which the stimulus leading to important advances often comes. The League's first effort in the field of nutrition was made in Japan, where an inquiry was held by the League at the request of the Japanese Government. In this work Australia has taken a leading part, notably through her delegate to the League Assembly, Mr. S. M. Bruce. Moreover, the committee set up under his chairmanship, and known as the Bruce Committee, has already pointed the way forward to social and economic developments of the utmost importance.

Important contributions have by no means been limited to the States members of the League. The success of the League's work in the field of opium and international health has been largely due to the co-operation of the United States. Throughout the last two decades the tendency has been for such co-operation in technical matters to increase, independently of the way in which the political situation might encourage or discourage American co-operation with the League in strictly political affairs. Experience does, indeed, suggest that the United States will be ready, after the War, to take a share in the economic reconstruction on which the hope of the recovery of Europe depends, and that there are no inherent obstacles in the League's 
organization to the constructive technical and economic work which must proceed side by side with, if not as a prelude to, political reconstruction.

Another significant feature in the technical work of the League which is noted by Mr. Sweetser deserves special attention. Delegates at Geneva handling such problems are often far ahead of their Governments at home. As perhaps might be expected, not only have they a strong sense of the urgency of the problems they are discussing, but also they tend to approach them from the professional point of view, with its desire for constructive and appropriate action. This urge to obtain an adequate technical solution to such problems is reinforced by the larger perspective in which the problems are viewed, and the corporate spirit inspired by the day-to-day process of give and take.

In contrast to this, ministers and officials at home are still in a national atmosphere, subject to all sorts of inhibitions and jealousies. The narrowing of this gap, between what a diplomatist viewing the world as a whole recommends and what a local politician at home is willing and able to accept, is indeed one of the great problems facing the future.

Much is involved in any such efforts at extending the cool, serious, and detached spirit of science into national and international government. The impartial examination of the facts is only the preliminary stage, and perhaps the most elementary contribution which professional organizations, whether of scientific workers or other types of experts, have to make to social advance. A wide vision, minds imaginatively alive to the human issues involved, cool in judgment, and willing, if need be, to sacrifice position or career rather than be false to the truth as they know it, or the vision they have seen-these are first among the qualities which will build us a new and better order. The measure in which they have been revealed in many ranks of society under the searching ordeal through which we are still passing is alike a sure pledge of victory and an earnest that we shall not fail to reap its fruits for all mankind.

\section{BIOLOGY FOR THE MILLION}

The Uniqueness of Man

By Dr. Julian Huxley. Pp. xiii +300 . (London : Chatto and Windus, 1941.) 10s. $6 d$. net.

"T "HE UNIQUENESS OF MAN" is a book full of good reading, very diversified. and occasionally very provocative, like the mind of its author. Julian Huxley is, among other things, the natural successor to Ray Lankester, the ripe and abundant author of "Science from an Easy Chair". These papers vary in quality from the admirable essay which gives the book its title to a cheery little review of "Who's Who", which lines up with its betters as "The Analysis of Fame". Such papers as "Climate and Human History", "The Origin of Species", "The Concept of Race", and "Mice and Men", are exactly what the man of intelligence, mainly preoccupied with other work, needs to keep him up to date with his biological ideas. The concluding three papers are 'religious' and very earnest in tone.

The title paper, written for the Yale Review, is done with a carefulness and precision not always evident in Dr. Huxley's fluent writing. It gives an extremely good survey of the profound gulf that has opened between Homo sapiens and the rest of the animal kingdom out of which he has arisen in the brief space of at most a quarter of a million years, a mere moment in geological time. This gulf was cleft open by conceptual thought. Already before then the anthropoid apes were an odd outstanding group of animals descending gingerly from the trees; but although their hands were comparatively free, Dr. Huxley tells us, they had no means of transmitting and handing on ideas. Then came words. With conceptual thought man established a mental and moral continuity and a power of assimilating social groups, additional to and far more effective than the links of consanguinity and physical inheritance $\mathrm{He}$ developed a novelty in the history of life, "cumulative tradition", and so by means of the word he escaped from the limitations of the small churlish family group hitherto characteristic of other anthropoids. That may not be wholly true. There may have been an intervening phase before the spoken word dominated us, when man had already achieved a certain power over general ideas by means of gesture. Many peoples can still converse by gestures with words as accessories. Man may have begun with gesture and mimicry, with grunts and sounds arising out of his movements. He may have been visual in his communications before he became vocal. He may have drawn and made tally marks long before he used common nouns or numerals in counting. 